
\title{
R Research Soure \\ Gynaecological health burden among women in the Niger Delta region of Nigeria: A hospital based analysis
}

Research

Keywords:

Posted Date: October 15th, 2020

DOl: https://doi.org/10.21203/rs.3.rs-86151/v2

License: (c) (i) This work is licensed under a Creative Commons Attribution 4.0 International License.

Read Full License 


\section{Abstract}

The authors have requested that this preprint be withdrawn due to author disagreement.

\section{Full Text}

The authors have withdrawn this preprint from Research Square. 